\title{
Envelope Proteins in Salmonella minnesota Mutants
}

\author{
By R. PARTON \\ Department of Microbiology, Glasgow University, Glasgow G6I I $Q H$
}

(Received 17 December 1974)

\begin{abstract}
SUMMARY
Envelope proteins of one smooth (S) strain and seven rough (R) mutants of Salmonella minnesota were examined by sodium dodecyl sulphate-polyacrylamide gel electrophoresis. All strains gave similar band patterns although some consistent differences were detected. A major polypeptide band at $54 \mathrm{k}$, which coincided with the flagellar component, was more prominent in $\mathrm{S}, \mathrm{Ra}$ and $\mathrm{Rb}$ than in the $\mathrm{Rc}$, $\mathrm{Rd}$ and $\mathrm{Re}$ chemotypes. The latter strains, however, showed more prominent bands at 48,19 and $18 \mathrm{k}$. The stage of growth at which the cultures were harvested was also found to affect the band patterns, particularly in the 54 and $40 \mathrm{k}$ regions. A closer examination of $\mathrm{S}, \mathrm{Ra}$ and $\mathrm{Re}$ strains suggested that the levels of the major 40 and $37 \mathrm{k}$ bands were slightly reduced in $\mathrm{Re}$. It is concluded that the progressive loss of lipopolysaccharide components which occurs from the S chemotype through various degrees of roughness to $\mathrm{Re}$ is accompanied by a change in the envelope protein composition, apparently between $\mathrm{Rb}$ and $\mathrm{Rc}$.
\end{abstract}

\section{INTRODUCTION}

Variation from 'smooth' to 'rough' in Gram-negative bacteria involves progressive loss of sugars in the lipopolysaccharide (LPS), with consequent changes in immunological specificity. This has been particularly thoroughly investigated in certain species of Salmonella, where strains have been isolated, with LPS, ranging from the fully smooth (S) type through varying degrees of roughness $(\mathrm{Ra}, \mathrm{Rb}, \mathrm{Rc}, \mathrm{Rd})$ to the extreme rough $(\mathrm{Re})$ type, which contains only 2-keto-3-deoxyoctonic acid, lipid A and ethanolamine. The progressive attenuation of LPS in these series of mutants reflects the stepwise loss of enzymes involved in saccharide synthesis or assembly.

In contrast to this detailed knowledge of changes in LPS during smooth-to-rough variation, little has been published on possible changes in cell envelope proteins which may also occur during these mutations and which may thus affect the immunological specificity of the cells. The possibility of investigating such changes has been greatly facilitated by the introduction of the sodium dodecyl sulphate-polyacrylamide gel electrophoresis (SDS-p.a.g.e.) technique. Recently this method was used to show that phase variation in Bordetella pertussis, which may be analogous to smooth-to-rough variation in Salmonella, involved the loss of one, and possibly two, major proteins of the cell envelope (Parton \& Wardlaw, 1975). In contrast, Morris (1973) found no changes in electrophoretic analyses of protein extracts of whole cells of smooth and rough Brucella strains. His results, however, were obtained by electrophoresis in the absence of SDS. Since starting this work, articles have appeared by Ames (1974), Ames, Spudich \& Nikaido (I974) and Koplow \& Goldfine (1974), the former group working along similar lines with S. typhimurium and the latter with Escherichia coli. Both groups have reported that rough mutants lack certain envelope proteins that are present in the smooth forms. Salmonella minnesota has a particularly extensive and well-characterized series of LPS mutants. The 
envelope proteins of these strains, as determined by SDS-p.a.g.e., form the subject of this report. It will be shown that smooth-to-rough variation involves both gains and losses in envelope protein components.

\section{METHODS}

Bacterial strains. One smooth and seven rough strains of $S$. minnesota were obtained from Dr G. Schmidt of the Max Planck Institut für Immunobiologie, Freiburg, Germany. The strain designations and chemotypes are shown in Table $\mathrm{I}$. The chemical compositions of the corresponding lipopolysaccharides are reported by Lüderitz et al. (I97I).

Media and growth. Stock cultures were grown on nutrient agar and, for larger scale growth, were inoculated into I 1 volumes of Nutrient Broth No. 2 (Oxoid), $2 \cdot 5 \%$ (w/v), in 21 flanged conical flasks. The flasks were shaken at $100 \mathrm{rev} . / \mathrm{min}$ at $37^{\circ} \mathrm{C}$ (or at $44{ }^{\circ} \mathrm{C}$ to inhibit production of flagella), usually for $\mathrm{I} 6 \mathrm{~h}$. Cells were collected by centrifugation at $4{ }^{\circ} \mathrm{C}$, washed once in saline $(0.85 \%, \mathrm{w} / \mathrm{v}, \mathrm{NaCl})$ and resedimented.

Envelope preparation. Packed cells were resuspended in saline at $4{ }^{\circ} \mathrm{C}$ and, after freezing, were broken by three passages through an LKB X-press. After thawing, the resulting suspension was diluted with saline and centrifuged at $100000 \mathrm{~g}$ for $30 \mathrm{~min}$. The opaque pellet was dispersed in distilled water using a syringe with a 23 gauge needle and the suspension recentrifuged. This washing procedure was repeated, and the deposit was again suspended in water and then centrifuged in a bench centrifuge for 10 min to remove unbroken cells and debris. The supernatant was centrifuged at $100000 \mathrm{~g}$ for $\mathrm{I} \mathrm{h}$ and the resulting envelope layer was removed, dispersed in a small volume of water and frozen until required.

Preparation of flagella. Cells were grown, collected and washed as described above, then suspended in $50 \mathrm{ml}$ cold saline. Flagella were removed by blending in a MSE homogenizer at full speed for $2 \mathrm{~min}$ with the flask cooled in an ice-water bath. The sheared cells were removed by centrifugation at $10000 \mathrm{~g}$ for $30 \mathrm{~min}$ at $4{ }^{\circ} \mathrm{C}$ then resuspended in saline and both the supernatant (containing sheared flagella) and the cell suspension were centrifuged again. Sheared cells were used for envelope preparation as described above. Flagella were either concentrated by dialysis against polyethylene glycol $4000(\mathrm{BDH})$ or were collected by centrifugation at $100000 \mathrm{~g}$ for $\mathrm{I} \mathrm{h}$.

Electrophoresis. Slab gel electrophoresis with a discontinuous SDS buffer system was based on the methods of Laemmli (1970) as modified by Ames et al. (1974). Separating and stacking gels contained 10 and $5 \%(\mathrm{w} / \mathrm{v})$ acrylamide, respectively. Both the gels and the electrode buffer contained $0.1 \%(w / v)$ SDS. The total dimensions of the slabs were approximately $8.0 \times 7.0 \times 0.3 \mathrm{~cm}$, the separating gels being $6.0 \times 7.0 \times 0.3 \mathrm{~cm}$.

Envelope samples were adjusted to contain $2 \mathrm{mg}$ protein $/ \mathrm{ml}$ as determined by the method of Herbert, Phipps \& Strange (I97I). To solubilize the envelopes, a $0.5 \mathrm{ml}$ sample was added to $0.5 \mathrm{ml}$ of $0.125 \mathrm{M}$-tris-HCl buffer $\mathrm{pH} 6.8$, containing $4 \%$ (w/v) SDS, Io $\%$ (v/v) $\beta$-mercaptoethanol, $20 \%(\mathrm{v} / \mathrm{v})$ glycerol and $0.002 \%(\mathrm{w} / \mathrm{v})$ bromophenol blue, and the mixture was heated to $100{ }^{\circ} \mathrm{C}$ for $5 \mathrm{~min}$ except where stated. The volume of sample mixture normally applied to the gels was between 25 and $50 \mu \mathrm{l}$.

Electrophoresis was done in a Uniscil slab gel electrophoresis unit (Universal Scientific $\mathrm{Ltd}$, London) at a constant current of $15 \mathrm{~mA} / \mathrm{gel}$ for approximately $2 \mathrm{~h}$. Staining and destaining was by the method of Weber \& Osborn (1969) except that the gels were destained by soaking in several changes of the destaining solution.

Densitometer traces of stained gels were obtained using a Joyce Loebl u.v. scanner. The instrument was modified to have an effective scanning aperture of $0.05 \mathrm{~mm}$ and was fitted with a $280 \mathrm{~nm}$ interference filter. 
Table I. Nomenclature and characteristics of $S$. minnesota strains

\begin{tabular}{|c|c|c|c|c|c|c|c|c|}
\hline \multirow[b]{2}{*}{$\begin{array}{c}\text { Strain } \\
\text { number }\end{array}$} & \multirow[b]{2}{*}{ Synonym } & \multirow[b]{2}{*}{$\begin{array}{l}\text { Chemo- } \\
\text { type }\end{array}$} & \multirow[b]{2}{*}{ Flagella* } & \multirow[b]{2}{*}{ Pili* } & \multirow{2}{*}{$\begin{array}{c}\text { Slide } \\
\text { aggluti- } \\
\text { nation } \\
\text { with } \\
0.3 \% \\
\text { auramine }\end{array}$} & \multicolumn{3}{|c|}{ Inhibition $\dagger$ (mm diam) } \\
\hline & & & & & & $\begin{array}{l}\text { Erythro- } \\
\text { mycin }\end{array}$ & $\begin{array}{c}\text { Crystal } \\
\text { violet }\end{array}$ & $\begin{array}{l}\text { Sodium } \\
\text { deoxy- } \\
\text { cholate }\end{array}$ \\
\hline SF I I I I & $\begin{array}{l}\text { S. minnesota } \\
\text { (smooth) }\end{array}$ & $\mathbf{S}$ & +++ & ++ & - & $<6$ & $<6$ & $<6$ \\
\hline SFI I I 2 & R60 & $\mathrm{Ra}$ & +++ & - & + & $<6$ & $<6$ & $<6$ \\
\hline SFI 127 & R345 & $\mathrm{Rb}$ & +++ & + & + & $<6$ & $<6$ & $<6$ \\
\hline SFI I I 9 & R5 & $\mathbf{R c}$ & + & \pm & + & 9 & 10 & $<6$ \\
\hline SFIIII & R7 & $\mathbf{R d}_{1}$ & + & - & + & II & 10 & $<6$ \\
\hline SFI 287 & $\mathbf{R Z}_{2}$ & $\mathbf{R d}_{1}$ & \pm & - & + & IO & 10 & 8 \\
\hline SFIII 7 & R3 & $\mathbf{R d}_{2}$ & $\overline{+}$ & \pm & + & 13 & 14 & 10 \\
\hline SFI I67 & R595 & $\operatorname{Re}$ & + & - & + & 17 & I6 & 17 \\
\hline
\end{tabular}

* Presence of flagella and pili was determined by electron microscopy of negatively-stained preparations: +++ , abundant; ++ , common; + , few; \pm , very few; - , none observed.

$\dagger$ Inhibition was tested on nutrient agar using paper discs $6 \mathrm{~mm}$ in diameter containing ro $\mu \mathrm{g}$ erythromycin, $10 \mu \mathrm{g}$ crystal violet or $\mathbf{2} \mathrm{mg}$ sodium deoxycholate.

For molecular weight determinations, the following marker proteins were run under identical conditions: bovine serum albumin (mol. wt $67 \mathrm{k}$; Sigma); yeast hexokinase (45k; Sigma); bovine pancreatic chymotrypsinogen (25.7k; Miles-Seravac, Maidenhead, Berkshire); trypsin (23k; Armour Pharmaceutical Co. Ltd, Eastbourne, Sussex); sperm whale myoglobin (17.2 k; Koch-Light); and horse-heart cytochrome $c$ (I I $7 \mathbf{k}$; Koch-Light). Each protein band is referred to by the estimated molecular weight obtained by interpotation on the scale provided by the marker proteins.

Electron microscopy. Cells were fixed for negative staining with formaldehyde (final concn. $4 \%, w / v)$, centrifuged and resuspended in distilled water. Suspensions were mixed with an equal volume of $2 \%(\mathrm{w} / \mathrm{v})$ phosphotungstic acid or $2 \%(\mathrm{w} / \mathrm{v})$ ammonium molybdate and dried on Formvar-coated copper grids.

\section{RESULTS}

\section{Preliminary characterization of strains}

The smooth strain and the seven rough mutants of $S$. minnesota were subjected to a variety of tests as shown in Table I. Electron microscopic examination for flagella and pili was made because of their possible contributions to the proteins in the envelope fraction. In the $\mathrm{I} 6 \mathrm{~h}$ cultures used for envelope preparations, flagella were abundant on the $S, R a$ and $R b$ strains. They were also detected on all the other strains but in much smaller numbers. Pili were only abundant on a proportion of cells of the smooth strain but were also observed, in small numbers, in $\mathrm{Rb}, \mathrm{Rc}$ and $\mathrm{Rd}_{2}$. None were detected on $\mathrm{Ra}, \mathrm{Rd}_{1}$ or $\mathrm{Re}$. It was thus apparent that smooth-to-rough variation in $S$. minnesota was accompanied by changes in these appendages in addition to changes in the LPS.

The slide agglutination and growth inhibition tests were used to differentiate between the $S$ form and the various $R$ mutants (Lüderitz et al. 197I; Ames et al. 1974), mainly as a check on the authenticity of the strains. Results of the slide agglutination test with $0.3 \%(\mathrm{w} / \mathrm{v})$ auramine agree with those of Schmidt et al. (1969a). Our finding that sensitivity to erythromycin, crystal violet and sodium deoxycholate increases from $\mathrm{Ra}$ to $\mathrm{Re}$ agrees closely with the results of systematic studies performed on these strains by Schmidt, Schlecht \& Westphal (I969b) and Schlecht \& Westphal (1970). 


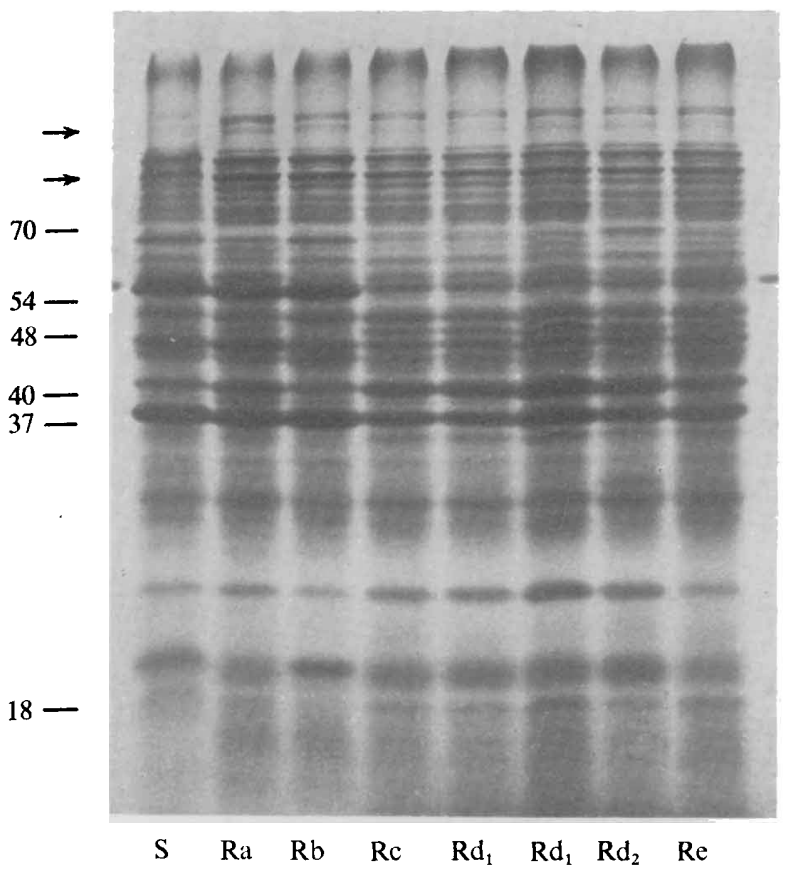

Fig. I

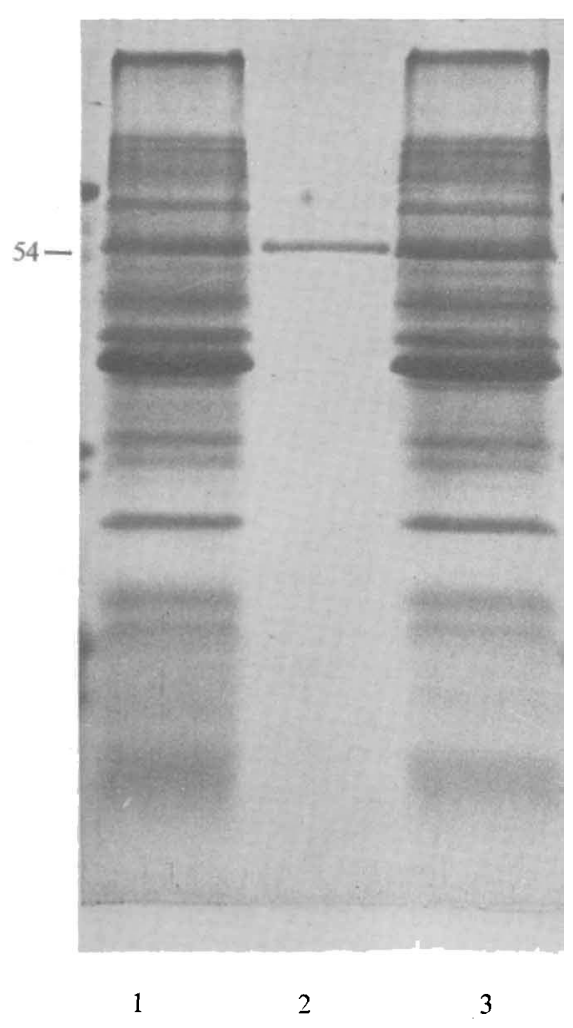

Fig. 2

Fig. I. Envelope protein profiles of the various chemotypes of $S$. minnesota from $\mathrm{I} 6 \mathrm{~h}$ cultures. Molecular weights (k-daltons) are given on the left.

Fig. 2. Envelope proteins obtained from unsheared (column I) and sheared (column 3) cells of the $\mathrm{S}$ strain run with isolated flagella (column 2).

\section{Comparison of envelope protein profiles}

In the initial part of this investigation, SDS-p.a.g.e. was done by the method previously used for Bordetella pertussis envelopes (Parton \& Wardlaw, 1975). However, since the publication of the paper by Ames et al. (1974) on S. typhimurium, the system used by these authors has been employed and has given much better resolution of the protein bands.

Fig. I shows the envelope protein profiles of all eight chemotypes of $S$. minnesota from I $6 \mathrm{~h}$ cultures. Envelopes were prepared from cultures grown on the same occasion and treated under identical conditions. The band patterns of the $\mathrm{S}, \mathrm{Ra}$ and $\mathrm{Rb}$ envelopes were very similar although the $S$ envelopes appeared to contain smaller amounts of certain high molecular weight ( $>70 \mathrm{k}$, i.e. $70 \mathrm{k}$-dalton) bands (arrowed) which were present in all the rough strains. The band patterns of the remaining $R c$ to $R e$ chemotypes were almost indistinguishable from each other but showed consistent differences from $S, R a$ and $R b$.

$\mathrm{S}, \mathrm{Ra}$ and $\mathrm{Rb}$ envelopes possessed a major band at $54 \mathrm{k}$ which was much diminished in the other strains. The latter, however, possessed bands at $48 \mathrm{k}$ and at about $\mathrm{I} 8 \mathrm{k}$ which were more prominent than in the $\mathrm{S}, \mathrm{Ra}$ and $\mathrm{Rb}$ strains. Some variation in the relative densities of the major bands at 40 and $37 \mathrm{k}$ was also noted. In $\mathrm{S}, \mathrm{Ra}$ and $\mathrm{Rb}$, and possibly $\mathrm{Re}$, the $37 \mathrm{k}$ 
band was the major band, whereas in the other strains the two bands were of approximately equal density. It was found, however, that the level of the $40 \mathrm{k}$ component varied significantly in $\mathrm{S}$ envelopes prepared on different occasions.

\section{Identification of flagellin band}

Because the strains differed markedly in their content of flagella, experiments were done to see if any of the apparent differences in envelope proteins were due to differences in this component. Flagella obtained from the S strain by shearing were run in parallel with envelopes from both sheared and unsheared cells (Fig. 2). The concentration of isolated flagella was adjusted, as closely as possible, to match that of flagella attached to unsheared cells. The flagellar protein band was found to coincide with the prominent $54 \mathrm{k}$ band in S, Ra and $\mathrm{Rb}$ envelopes. These strains were the only ones containing large numbers of flagella (see Table I). There was no apparent difference between the band patterns of the envelopes from sheared and unsheared cells even though the former no longer possessed significant numbers of flagella when examined by electron microscopy. In addition, when envelopes from sheared cells of the $\mathrm{S}, \mathrm{Rd}_{2}$ and $\mathrm{Re}$ strains were compared, they showed the same band differences as envelopes from unsheared cells. Flagella prepared from the $S$ strain on several different occasions and from the $\mathrm{Rb}$ and $\mathrm{Re}$ strains were indistinguishable and gave only a single band at $54 \mathrm{k}$.

Because the envelopes from sheared and unsheared cells showed no apparent difference in the $54 \mathrm{k}$ region, additional experiments were made to determine whether flagella accounted for the major part of the $54 \mathrm{k}$ band or whether they simply gave a band coincident with a major $54 \mathrm{k}$ component of the envelope. Envelopes were prepared from cells grown at $44{ }^{\circ} \mathrm{C}$ to inhibit production of flagella (Kerridge, I96I). Growth of $S$. minnesota at $44{ }^{\circ} \mathrm{C}$ was found to inhibit production of flagella as determined by electron microscopy. Again there was no apparent difference from bacteria grown at $37{ }^{\circ} \mathrm{C}$ in the $54 \mathrm{k}$ region, though minor bands in other regions of the gel did change. Thus the difference between the abundantly flagellate strains $\mathrm{S}, \mathrm{Ra}$ and $\mathrm{Rb}$ and the other, sparsely flagellate, strains could not definitely be attributed to differences in numbers of flagella.

Pili did not appear to be removed from the S strain by the shearing procedure and consequently no visible band corresponding to pili was obtained in the flagellar preparation. Only the $S$ and $R b$ cells in these particular cultures were found to possess many pili and the envelope profiles of these strains could not readily be differentiated from that of the nonpiliated $\mathrm{Ra}$ strain. It was presumed, therefore, that these appendages did not influence the envelope band patterns either because they were present in too small amounts or because the pili band coincided with a more prominent envelope band.

\section{Effect of growth phase}

Schnaitman (1974b) has shown that the outer membrane protein profiles of $E$. coli strains and other enteric bacteria could be significantly affected by the stage of growth at which the cultures were harvested. In the present work, comparison of $S$. minnesota envelope proteins was initially carried out using cells routinely grown overnight for $\mathrm{I} 6 \mathrm{~h}$. To determine whether some of the differences between the strains were due to differences in growth rates, envelopes were prepared from various strains harvested either at the same stage of exponential growth or several hours after the end of the exponential phase.

Figure 3 shows the growth curves of the $\mathrm{S}, \mathrm{Ra}$ and $\mathrm{Re}$ strains and the times at which the cultures were harvested. The bacteria were initially grown overnight at $37^{\circ} \mathrm{C}$ on nutrient agar plates and then inoculated into $100 \mathrm{ml}$ amounts of nutrient broth. After incubation for 


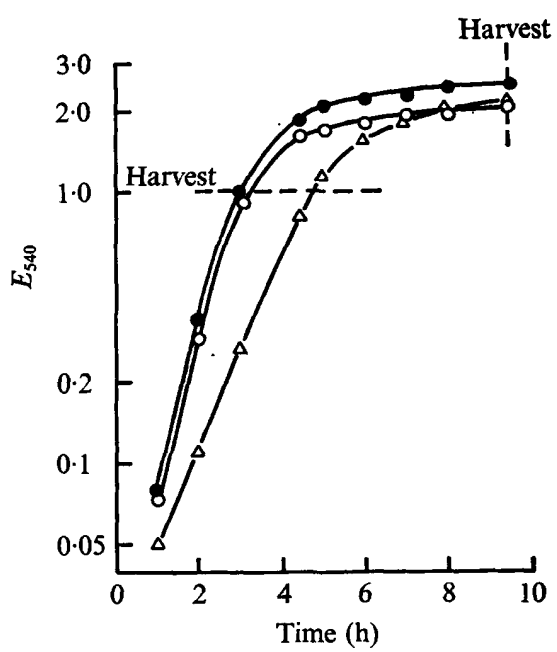

Fig. 3. Extinction changes in cultures of the $S(\bullet), \operatorname{Ra}(0)$, and $\operatorname{Re}(\Delta)$ strains grown in nutrient broth. Envelopes were prepared from cells harvested at the points indicated.

$4 \mathrm{~h}$, these cultures were adjusted to the same extinction values and $7 \mathrm{ml}$ of each were used to inoculate $700 \mathrm{ml}$ of nutrient broth. The $\mathrm{S}$ and $\mathrm{Ra}$ strains grew at approximately the same rate for about $4 \mathrm{~h}$ but the final turbidity of the $S$ culture was greater than that of the Ra strain. The $\operatorname{Re}$ strain grew more slowly, but after $7 \mathrm{~h}$ the turbidity of the culture had equalled that of the Ra strain. Cultures of each strain were harvested in the exponential phase (e.p.), when they had reached an $E_{540}$ of $\mathrm{r} \cdot 0$. Cultures grown in parallel were harvested after $9 \frac{1}{2} \mathrm{~h}$ when exponential growth had ceased, though some increase in extinction was still taking place. These cultures were thus termed post-exponential phase (p.e.p.).

Densitometer traces of the envelope protein profiles of the $S$ strain from e.p. and p.e.p. cultures and from the $\mathrm{I} 6 \mathrm{~h}$ culture grown previously are shown in Fig. 4. The profiles show major differences in two regions. The $54 \mathrm{k}$ band was found to increase in intensity from e.p. to p.e.p. envelopes. This change was paralleled by an increase in the number of flagella as seen by electron microscopy and presumably reflects an increase in the amount of flagellin in the envelope fraction. The $40 \mathrm{k}$ band, which was a major band in both the e.p. and p.e.p. envelopes, was greatly decreased in the $16 \mathrm{~h}$ preparation. In adition, the $\mathrm{I} 6 \mathrm{~h}$ profile showed an increase in a band at $45 \mathrm{k}$.

The preparations from the Ra strain showed a similar change in the $54 \mathrm{k}$ band. Both $\mathrm{Ra}$ and Re strains showed a slight loss of the $40 \mathrm{k}$ band in the $16 \mathrm{~h}$ preparation but this was not as marked as in the $S$ strain. Otherwise, all three preparations were very similar in both the $\mathrm{Ra}$ and Re strains.

When e.p. or p.e.p. 'envelope profiles of the $\mathrm{S}, \mathrm{Ra}$ and $\mathrm{Re}$ strains were compared, similar differences were observed. Densitometer traces of the p.e.p. envelopes are shown in Fig. 5. The changes were similar to those seen in the envelopes from $16 \mathrm{~h}$ cultures (Fig. I). The major $54 \mathrm{k}$ band in $\mathrm{S}$ and $\mathrm{Ra}$ envelopes was much diminished in Re but the latter strain possessed increased amounts of the $48 \mathrm{k}$ band and two bands at about 18 and $19 \mathrm{k}$. The major 40 and $37 \mathrm{k}$ bands showed the same relative densities in all three strains, but the Re strain appeared to contain slightly less of both of these bands. Also, high molecular weight ( $>70 \mathrm{k}$ ) bands in $\mathrm{S}$ were present in increased amounts in the $\mathrm{Ra}$ and $\mathrm{Re}$ form. It should be noted that the resolution of these bands in the envelope profile of the $S$ strain varied in different gels but 


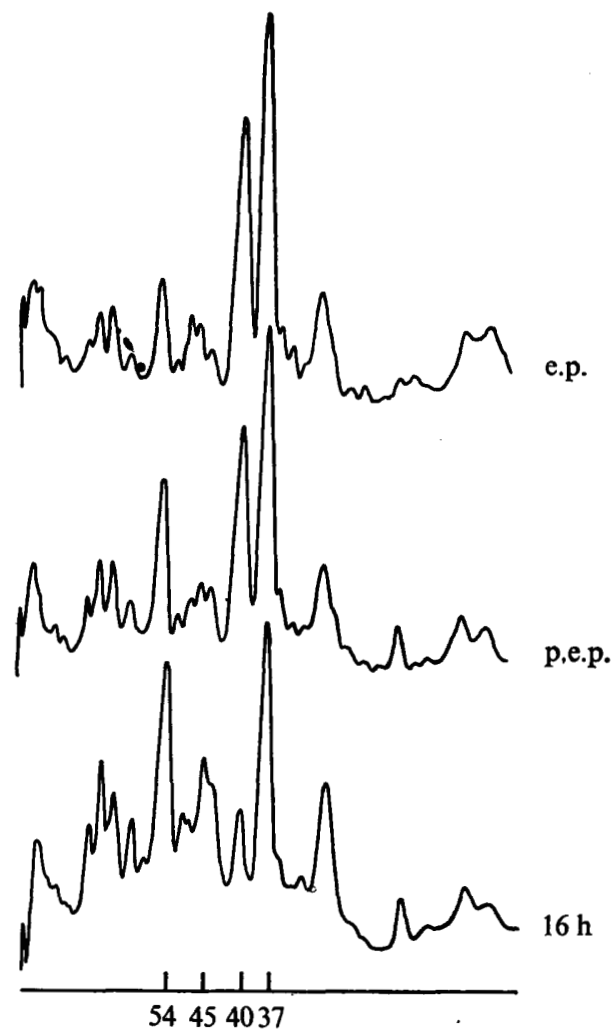

Fig. 4

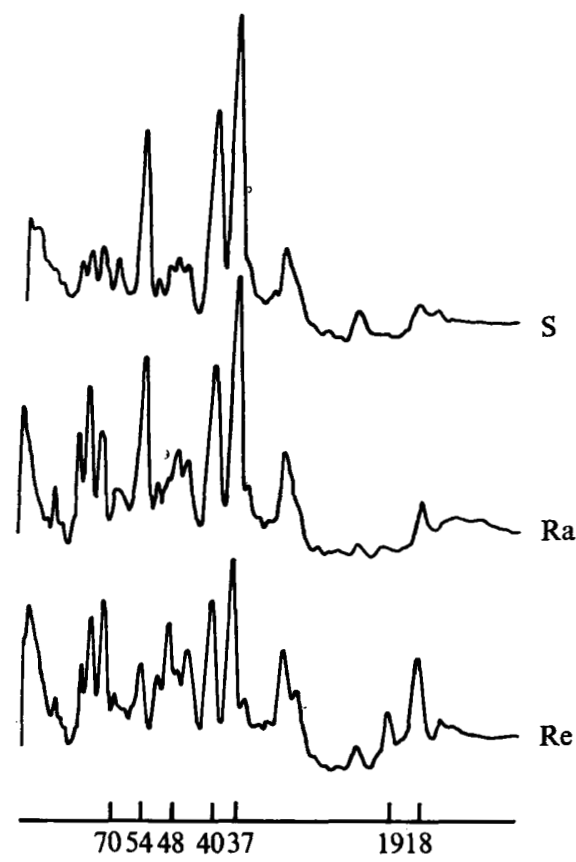

Fig. 5

Fig. 4. Densitometer traces of $S$. minnesota $S$ envelope proteins prepared from cells harvested in exponential phase (e.p.) or post-exponential phase (p.e.p.) and compared with a sample from a $16 \mathrm{~h}$ culture prepared on a previous occasion. The molecular weights of prominent bands (k-daltons) are indicated; they were obtained as described in Methods.

Fig. 5. Densitometer traces of the envelope proteins prepared from p.e.p. cells of the $S, R a$ and $R e$ chemotypes.

could be improved if the concentration of SDS in the upper electrode buffer and in the stacking gel was increased from 0.1 to $0.2 \%(w / v)$. The differences between the smooth form and the rough mutants in this region may therefore be more apparent than real.

\section{Effect of temperature of solubilization}

Previous work has shown that the temperature of solubilization may affect the band pattern of envelope proteins in SDS-p.a.g.e. (Schnaitman, 1973; Ames et al. 1974; Parton \& Wardlaw, 1975). In an attempt to resolve further possible differences between the envelope proteins of the different chemotypes, envelopes which had been solubilized at $37^{\circ} \mathrm{C}$ for $30 \mathrm{~min}$ were compared with those solubilized at the usual $100{ }^{\circ} \mathrm{C}$ for $5 \mathrm{~min}$. Figure 6 shows the band patterns of the $S$ and Re chemotypes, obtained from $\mathrm{I} 6 \mathrm{~h}$ cultures, after solubilization at the two temperatures.

A comparison of the $\mathrm{S}$ and Re preparations solubilized under the usual conditions (Fig. 6, columns 2 and 3 respectively) reveals the same differences as described earlier. Both preparations showed similar changes in their band patterns when solubilization was done at $37^{\circ} \mathrm{C}$ 


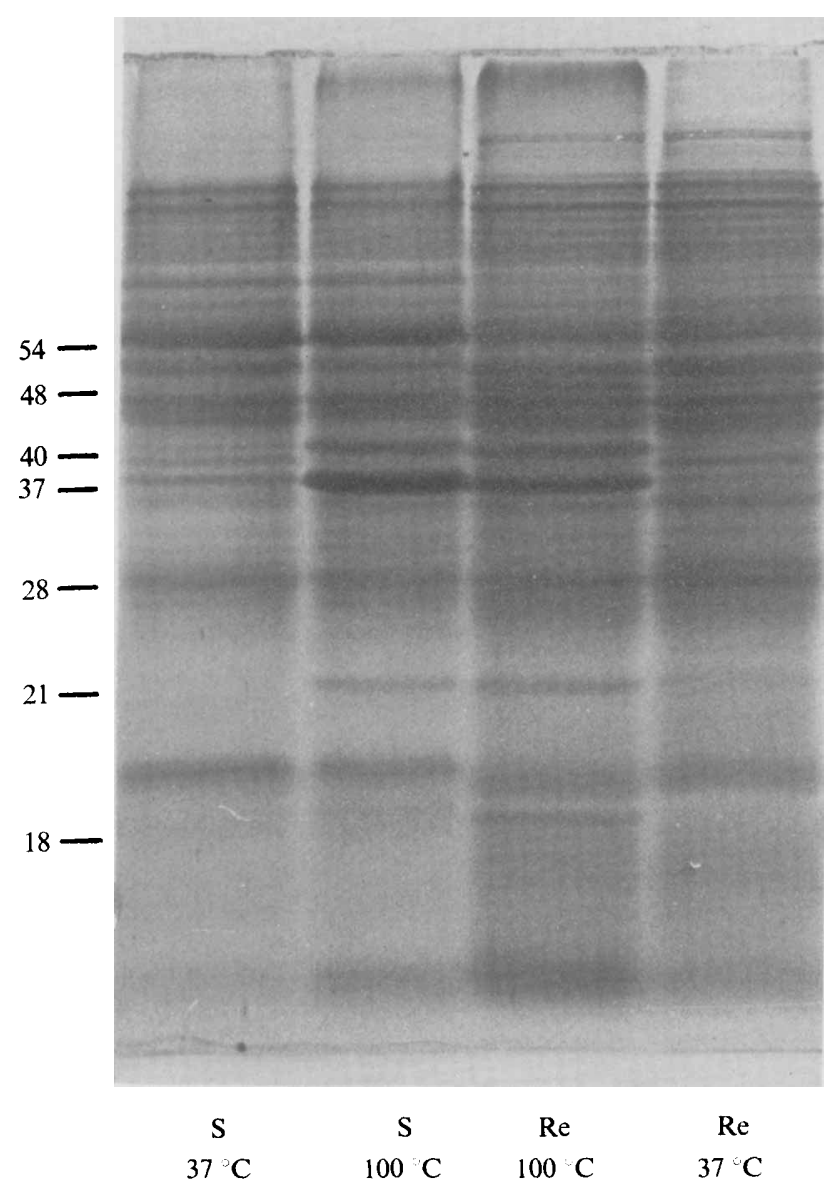

Fig. 6. Envelope protein profiles of $\mathrm{S}$ and $\mathrm{Re}$ chemotypes obtained from $\mathrm{I} 6 \mathrm{~h}$ cultures. Solubilization was at $100{ }^{\circ} \mathrm{C}$ for $5 \mathrm{~min}$ or at $37^{\circ} \mathrm{C}$ for $30 \mathrm{~min}$.

for $30 \mathrm{~min}$ (columns I and 4). The most striking change was that the major bands in the I00 ${ }^{\circ} \mathrm{C}$ profile ( 37 and $40 \mathrm{k}$ ) were much reduced in the $37^{\circ} \mathrm{C}$ profile. Another band at $2 \mathrm{I} \mathrm{k}$ was also significantly reduced. On the other hand, three bands (50, 38.5 and $28 \mathrm{k}$ ) appeared to be more prominent in the $37^{\circ} \mathrm{C}$ profile. In addition, the 48 and $18 \mathrm{k}$ bands, present only in the $\mathrm{Rc}$ to $\mathrm{Re}$ chemotypes, appeared to be somewhat diminished in the $37^{\circ} \mathrm{C}$ profile.

These differences are presumably due to differences in susceptibility of the proteins to solubilization, since the typical $100{ }^{\circ} \mathrm{C}$ profile could be obtained when a sample already solubilized at $37^{\circ} \mathrm{C}$ was heated to $100{ }^{\circ} \mathrm{C}$. Thus, although solubilization temperature affected the envelope protein profiles, similar changes occurred in the smooth and rough strains and no further differences in protein composition could be demonstrated in this way.

\section{DISCUSSION}

Salmonella minnesota resembles other Gram-negative bacteria whose envelopes have been examined by SDS-p.a.g.e. in showing a complex pattern of at least 40 polypeptide bands. This presumably reflects the minimum number of different polypeptides in the envelope since each band may contain two or more polypeptide species which happen to have the 
same mobility. The finding of Schnaitman (1974a) that the major outer membrane band of $E$. coli obtained by SDS-p.a.g.e. at neutral $\mathrm{pH}$ is composed of four distinct polypeptide groups, supports this interpretation. This must be borne in mind when interpreting changes in the density of a band. For example, a reduction in density could be due to a partial loss of a single component or to the complete loss of one polypeptide group from a mixture.

Schnaitman (1974b) has shown that the relative levels of the major outer membrane proteins of $E$. coli, Salmonella and Shigella strains depend on the stage of growth at which cultures are harvested. Changes in envelope protein composition have also been shown in E. coli cells in which DNA synthesis or cell division was altered (Inouye \& Pardee, I970; Siccardi et al. I97I; Siccardi, Lazdunski \& Shapiro, 1972). In the present study, the envelope protein profiles of exponential-phase cells were compared with those of cells in which exponential growth had ceased, though because a complex medium was used some growth was still taking place. No major differences were seen except one in the $54 \mathrm{k}$ region which appeared to be due to a change in flagellar content. Envelope profiles of older ( $16 \mathrm{~h}$ ) cultures, however, particularly in the smooth strain, showed a decrease in the major $40 \mathrm{k}$ band. It is therefore essential when comparing the envelope proteins of different strains to ensure that all strains are at the same stage of growth. The variations in the level of the $40 \mathrm{k}$ band could represent a true difference between the various chemotypes but are more likely due to differences in the state of growth of the cultures.

Recent studies by Ames et al. (1974) have shown that certain major envelope polypeptides of S. typhimurium were lost or diminished in extreme rough $\left(\mathrm{Rd}_{2}\right.$ and $\left.\mathrm{Re}\right)$ mutants derived from this strain. They also showed that the polypeptides were major components of the outer membrane portion of the envelope. Similar findings were made by Koplow \& Goldfine (1974) when they examined extreme rough mutants of $E$. coli. The present observations on $S$. minnesota indicate that although changes in envelope protein composition do occur during smooth-to-rough variation, these changes are not as marked as those in S. typhimurium and $E$. coli and are not all deletion changes.

One difficulty encountered in interpreting the changes in band patterns was due to differences in numbers of flagella in the various strains. The band produced by isolated flagella was found to coincide with the major $54 \mathrm{k}$ band present in the abundantly flagellate $\mathrm{S}, \mathrm{Ra}$ and $\mathrm{Rb}$ strains. The other, sparsely flagellate, strains showed only a minor band in this region. However, envelopes from sheared cells of the $\mathrm{S}$ strain or from cells grown at $44{ }^{\circ} \mathrm{C}$ to inhibit flagellar formation still showed a heavy band at $54 \mathrm{k}$, even though the cells did not contain significant numbers of flagella. The shearing procedure could possibly have left flagellar fragments still attached to the envelope though it is unlikely that this would account for the major part of the band. Similarly, if growth at $44^{\circ} \mathrm{C}$ inhibited assembly of flagella rather than synthesis of flagellin, some of this constituent would probably be present in the envelope. These results were surprising, for differences in the $54 \mathrm{k}$ band could be seen in the e.p. and p.e.p. envelopes where the difference in the numbers of flagella was much less marked. One explanation which fits these observations is that only a minor part of the flagellin or $54 \mathrm{k}$ component is present actually in flagella and the rest is normally contained in the envelope, though no further evidence for this is available.

Ames et al. (1974) showed that their strains of $S$. typhimurium contained two types of flagella, namely phase $I$ and phase 2 . The phase $I$ and 2 flagellins gave two heavy bands in the envelope profile at 50 and $57 \mathrm{k}$ which were clearly absent from the envelopes of the nonflagellate extreme rough strains. In the previous paper (Ames, 1974) the relative amounts of these two bands were seen to vary (depending on the phase of the flagella) in whole cell profiles of otherwise isogenic strains. 
In addition to the loss of the $54 \mathrm{k}$ band in the $\mathrm{Rc}$ to $\mathrm{Re}$ chemotypes, the $\mathrm{Re}$ strain appeared to contain slightly less of the major 40 and $37 \mathrm{k}$ bands. This change may have been common to all strains from $\mathrm{Rc}$ to $\mathrm{Re}$, since their envelope protein profiles from $\mathrm{I} 6 \mathrm{~h}$ cultures were very similar. The 40 and $37 \mathrm{k}$ bands possibly corresponded to the major outer membrane proteins of $S$. typhimurium (Ames et al. 1974) since both groups of proteins are solubilized at $100{ }^{\circ} \mathrm{C}$ but not at $37^{\circ} \mathrm{C}$. There was, however, no marked loss of these proteins in the extreme rough $(\mathrm{Re})$ strain of $S$. minnesota, as observed in the corresponding strains of both S. typhimurium and E. coli.

In addition to the losses of protein material in $\mathrm{Rc}$ and $\mathrm{Rd}$, certain bands appeared to be more prominent in these strains. In particular, a band at $48 \mathrm{k}$ in $\mathrm{Rc}$ to $\mathrm{Re}$ strains was not clearly defined in the S, Ra and Rb strains. Koplow \& Goldfine (1974) found that their heptose-deficient strain of $E$. coli contained a band at $38 \mathrm{k}$ which was not present in the parent strain. This band appeared to be a component of the cytoplasmic membrane.

Ames et al. (1974) and Koplow \& Goldfine (1974) showed that the protein changes in $S$. typhimurium and $E$. coli took place in the outer membrane, though they could also be seen in envelope or even whole-cell protein profiles. It therefore seems unlikely that the apparent lack of differences in $S$. minnesota was due to the different method of envelope preparation or that the differences were obscured by the cytoplasmic membrane proteins.

Ames et al. (1974) and Koplow \& Goldfine (I974) have suggested that the loss of outer membrane proteins and the alterations in the LPS of the rough mutants result from a single mutation and that this could indicate a close association between these components. Both groups of workers have isolated revertants from the extreme rough strains which have regained the wild-type LPS and have also regained normal levels of the proteins. It was suggested that the proteins might need LPS components in order to be incorporated into the membrane, or vice versa. If so, the study of a series of chemotypes as in $S$. minnesota might help to determine how this association occurs. In the present investigation, the main change in envelope proteins occurred between $R b$ and $R c$ where changes in the composition of the pentasaccharide region of the basal core take place (Lüderitz et al. 1971).

Finally, the finding that the temperature of solubilization of the envelope proteins can markedly affect band patterns has been widely reported. The bands which show changes with temperature are also the ones which are lost in smooth-to-rough variation in S. typhimurium (Ames et al. 1974) and E. coli (Koplow \& Goldfine, 1974) and in phase variation in B. pertussis (Parton \& Wardlaw, 1975). In S. minnesota the 37 and $40 \mathrm{k}$ bands which are not present in the $37^{\circ} \mathrm{C}$ profiles, are also slightly diminished in the Re forms. Possible reasons for the unusual behaviour of the proteins with these solubilization temperatures have been suggested (Schnaitman, 1973; Ames et al. 1974). This behaviour might in some way reflect certain properties and therefore certain functions (such as the interaction with LPS discussed above) which are no longer essential in the envelopes of the rough strains.

I am grateful to Professor A. C. Wardlaw for his interest in this work and for his advice in the preparation of the manuscript. I thank the M.R.C. for financial support during this investigation. 


\section{REFERENCES}

AMES, G. F. (1974). Resolution of bacterial proteins by polyacrylamide gel electrophoresis on slabs. Membrane soluble and periplasmic fractions. Journal of Biological Chemistry 249, 634-644.

Ames, G. F., SpUdich, E. N. \& NiKaIDo, H. (1974). Protein composition of the outer membrane of Salmonella typhimurium: effect of lipopolysaccharide mutations. Journal of Bacteriology 117, 406-4I6.

Herbert, D., Phipps, P. J. \& Strange, R. E. (I97I). Chemical analysis of microbial cells. In Methods in Microbiology, vol. 5 B, pp. 209-344. Edited by J. R. Norris and D. W. Ribbons. London and New York: Academic Press.

INOUYE, M. \& PARDEe, A. B. (1970). Changes of membrane proteins and their relation to deoxyribonucleic acid synthesis and cell division of Escherichia coli. Journal of Biological Chemistry 245, 5813-5819.

KERRIDGE, D. (196I). The effect of environment on the formation of bacterial flagella. Symposia of the Society for General Microbiology 11, 4I-68.

Koplow, J. \& GoldFINE, H. (1974). Alterations in the outer membrane of the cell envelope of heptosedeficient mutants of Escherichia coli. Journal of Bacteriology 117, 527-543.

LAEMMLI, U. K. (1970). Cleavage of structural proteins during the assembly of the head of bacteriophage T4. Nature, London 227, 680-685.

Lüderitz, O., WestPhal, O., Staub, A. M. \& Nikaido, H. (I971). Isolation and chemical and immunological characterization of bacterial lipopolysaccharides. In Microbial Toxins, vol. 4, pp. 145-233. Edited by G. Weinbaum, S. Kadis and S. J. Ajl. New York and London: Academic Press.

MorRIs, J. A. (1973). The use of polyacrylamide gel electrophoresis in taxonomy of Brucella. Journal of General Microbiology 76, $231-237$.

Parton, R. \& Wardlaw, A. C. (1975). Cell envelope proteins of Bordetella pertussis. Journal of Medical Microbiology 8, 47-57.

SchleChT, S. \& WestPhAL, O. (1970). Untersuchungen zur Typisierung von Salmonella-R-Formen. IV. Mitteilung: Typisierung von S. minnesota-R-Mutanten mittels Antibiotica. Zentralblatt für Bakteriologie, Parasitenkunde, Infektionskrankheiten und Hygiene (Abteilung I) 213, 356-38I.

SChMidT, G., SCHLECht, S., LüDeritz, O. \& WeStPhAl, O. (I969a). Untersuchungen zur Typisierung von Salmonella-R-Formen. I. Mitteilung: Mikrobiologische und serologische Untersuchungen an Salmonella minnesota-Mutanten. Zentralblatt für Bakteriologie, Parasitenkunde, Infektionskrankheiten und Hygeine (Abteilung I) 209, 483-496.

Schmid, G., SChlecht, S. \& WestPhal, O. (1969b). Untersuchungen zur Typisierung von Salmonella-RFormen. III. Mitteilung: Typisierung von S. minnesota-Mutanten mittels chemischer Agenzien. Zentralblatt für Bakteriologie, Parasitenkunde, Infektionskrankheiten und Hygiene (Abteilung I) 212, 88-96.

SCHNATMAN, C. A. (1973). Outer membrane proteins of Escherichia coli. I. Effect of preparative conditions on the migration of protein in polyacrylamide gels. Archives of Biochemistry and Biophysics 157, 54I-552.

SchnaItman, C. A. (1974a). Outer membrane proteins of Escherichia coli. III. Evidence that the major protein of Escherichia coli on I I outer membrane consists of four distinct polypeptide species. Journal of Bacteriology 118, 442-453.

SchNatTMAN, C. A. (I974b). Outer membrane proteins of Escherichia coli. IV. Differences in outer membrane proteins due to strain and cultural differences. Journal of Bacteriology Ir8, 454-464.

Siccardi, A. G., LAZDUnSki, A. \& ShapiRo, B. M. (1972). Interrelationship between membrane protein composition and deoxyribonucleic acid synthesis in Escherichia coli. Biochemistry II, 1573-1 582.

Siccardi, A. G., Shapiro, B. M., Hirota, Y. \& JACOB, F. (I97I). On the process of cellular division in Escherichia coli. IV. Altered protein composition and turnover of the membranes of thermosensitive mutants defective in chromosomal replication. Journal of Molecular Biology 56, 475-490.

WEBER, K. \& OSBORN, M. (1969). The reliability of molecular weight determinations by dodecyl sulphate polyacrylamide gel electrophoresis. Journal of Biological Chemistry 244, 4406-4412. 